УДК 621.87

DOI 10.36910/6775-2313-5352-2020-17-21

Фльонц О.В., Кирик О.М.

Відокремлений підрозділ Національного університету біоресурсів і природокористування України «Бережанський агротехнічний інститут»

\title{
КОНТРОЛЬНИЙ ПРИСТРІЙ ДЛЯ ЗАМІРУ ПАРАМЕТРІВ ШЛІЦЕВИХ ВАЛІВ СІЛЬСЬКОГОСПОДАРСЬКИХ МАШИН
}

Описано види иліцевих з'єднань та актуальність теми, приведено технічні умови точності при виготовленні $i$ відновленні иліцевих валів сільськогосподарських машин. Розроблена конструкція контрольного пристрою для заміру конструктивних параметрів $i$ шорсткості при їх виготовленні і відновленні. Пристрій для заміру параметрів шліцевих валів виконано у вигляді плити, на якій розміщено основні вузли і деталі. Всі покази надходять через аналогово-цифровий перетворювач до електронно обчислювальної машини $і$ профілографопрофілометром. Крім цьього для заміру інших конструктивних параметрів шліцевого вала $i$ шорсткості інших поверхонь можуть встановлюватися додаткові датчики аналогічно вищевказаним. Вказана послідовність роботи пристрою: в цуентри ділильної головки $і$ задній центтр встановлюється еталонний шлічевий вал, з якого за допомогою індуктивних датчиків знімаються всі контрольовані параметри і шорсткість поверхні і встановлюють їх допустимі межі. Приведено визначення величини допустимої похибки встановлення. Визначено вимогу, яку повинна задовольняти схема встановлення заготовки. Зроблено висновки щодо проведених досліджень.

Ключові слова: з'єднання, вал, шорсткість, параметри, похибка.

Вступ. Шліцеві з'єднання набули широких масштабів використання в сільськогосподарських машинах, тому питання їх експлуатації і відновлення мають важливе значення. Вони можуть бути рухомими, які використовуються при встановленні шестерень в коробках передач автомобілів, тракторів, верстатів на шліцевих валах, або нерухомими нерухоме закріплення шківів, зубчастих коліс, муфт, маховиків на шліцевих валах.

Огляд та аналіз попередніх досліджень. Питання контролю якості шліцевих валів (ШВ) присвячено цілий ряд робіт $[1,2,3]$, однак цілий ряд питань залишилися невирішеними.

Тому метою даної роботи є розробка конструкції і принципу роботи контрольного пристрою для заміру конструктивних параметрів ШВ і шорсткості їх поверхонь.

Виклад основного матеріалу. В машинобудуванні шліцеві вали можуть бути 3 наскрізними і закритими шліцами, останні складають 65\% від загальної кількості типорозмірів. За конструкцією шліци можуть бути прямобічними, які складають $85 . .90 \%$ від загальної кількості валів, які використовуються в машинобудуванні.

Технічні вимоги до шліцевих з'єднань: - посадочні поверхні ШВ виготовляють по $6 . .7$ квалітетам точності з шорсткістю поверхонь $R_{a} \approx 1,25 \ldots 2,5$ мкм, а допуски радіального биття відносно осі складають 0,04...0,06 мм. Допуски паралельності шліців відносно осі і симетричності відносно діаметральної площини вала становлять 0,03...0,05 мм на 100 мм довжини.

Пристрій для заміру параметрів шліцевих валів, який зображено на рис.1 виконано у вигляді плити 1, на якій розміщено основні вузли і деталі. На плиті 1 розміщено правий 2 i лівий 3 рухомі блоки, які переміщується за допомогою гвинтів 4 вздовж направляючих 5, які 3 одного боку знаходяться у передніх стійках 6, а з другого - у задніх стійках 7, за допомогою електродвигуна 8. Рухомі блоки лівої 3 і правої 2 стійок містять обертові датчики $(\mathrm{OД} 1) 9$, які контактують із зубчастими рейками 10 через зубчасті колеса 11, які розміщені на індикаторних блоках 12, що переміщується вздовж направляючих 13, розміщених на рухомих блоках 2 i 3.

Індикаторні блоки містять корпуси індикаторів 14 в яких розміщено індикаторні датчики (ІД1) 15, рухомі стержні 16 яких знаходиться в контакті з лапками 17 до яких приєднано щупи 18, що заміряють конструктивні параметри, а щуп 19 шорсткість поверхні шліцевого вала 20.

На рухомих блоках 2 і 3 також розміщені штанги 21, на яких закріплені направляючі 22 , вздовж яких переміщуються індикаторні блоки 23, що містять індуктивні датчики (IД2) 24 , нерухомі 25 та рухомі губки 26, з’єднані із індуктивними датчиками. 
Всі покази датчиків надходять через аналогово-цифровий перетворювач (АЦП) 27 до електронно обчислювальної машини (ЕОМ) 28 і профілографо-профілометром 29. Крім цього для заміру інших конструктивних параметрів шліцевого вала 20 і шорсткості інших поверхонь можуть встановлюватися додаткові датчики аналогічно вищевказаним.

Шліцеві вали своїми центральними отворами встановлюються в центри 30 ділильної головки і задній центр 31 пристрою.

Робота пристрою здійснюється в такій послідовності.

Спочатку в центри ділильної головки 30 і задній центр 31 встановлюється еталонний шліцевий вал 20 з якого за допомогою індуктивних датчиків (ІД2) і (ІД2) знімаються всі контрольовані параметри і шорсткість поверхні і встановлюють їх допустимі межі.

Після цього його знімають і встановлюють шліцевий вал 20, який піддається замірам, у ділильну головку 30 і фіксується центром 31. Вмикається ЕОМ 28 і АЦП 27 і профілометрпрофілограф 29. Рухомий блок 2 підводиться до краю шліцевого вала 20 і встановлюються щупи 18 і 19 індикаторного блоку 11 на поверхню впадини шліца та губки 25, 24 на бокові поверхні шліців. Причому одночасно із встановленням вимірних елементів 17, 18, 25, 24 реєструються розміри, відповідно радіус впадин шліцевого вала 20 (датчиком ОД1), та ширину шліца, а також шорсткість поверхні датчиком 19. Вмикається електродвигун 7 і здійснюється переміщення рухомого блока 2 із вимірними елементами вздовж направляючої 4.
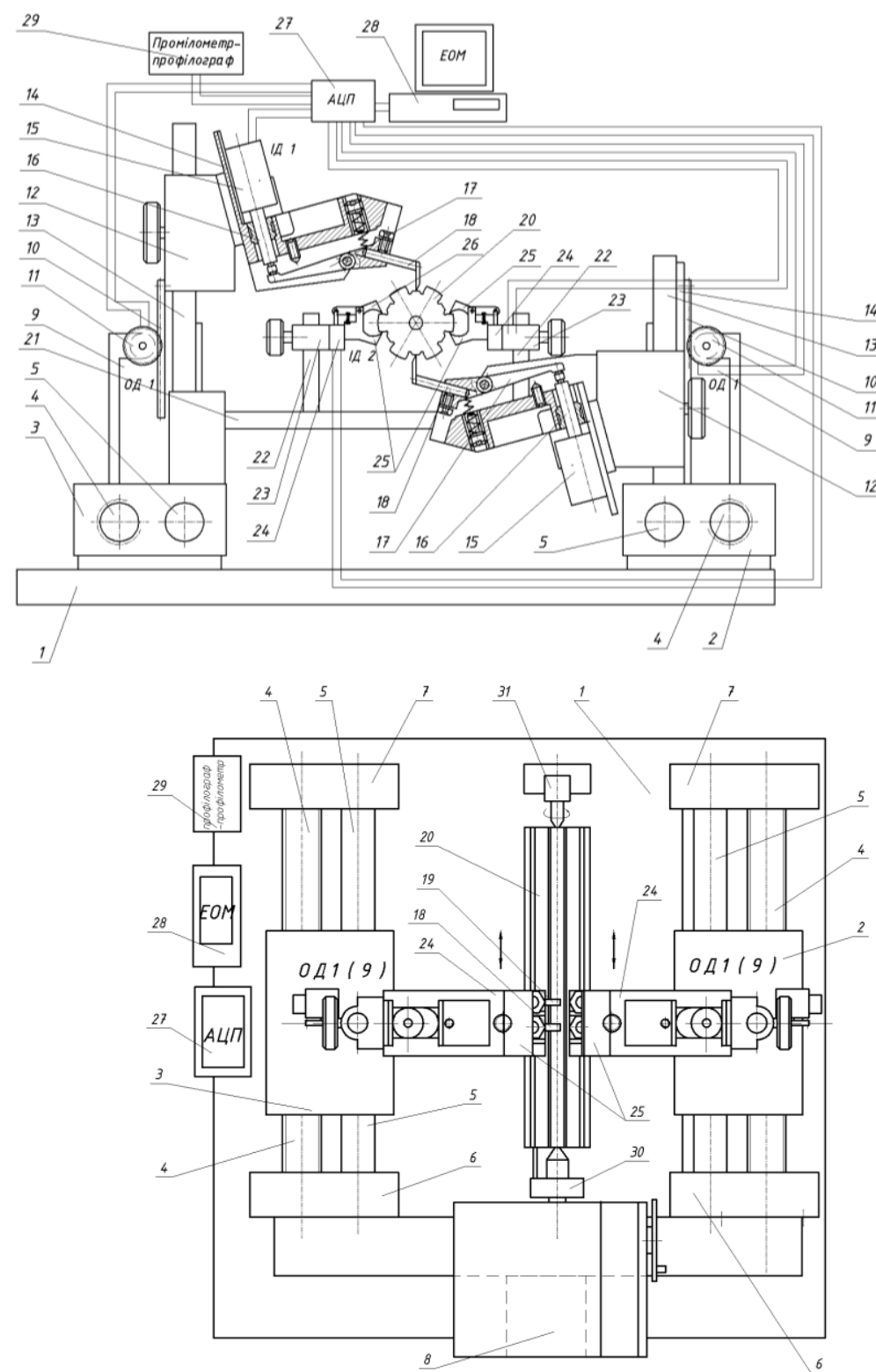

Рис. 1. Контрольний пристрій для заміру параметрів шліцевих валів

Внаслідок коливання щупа 17 та рухомих губок 25 по нерівностях шліцевого вала 20 
відбувається зміна індуктивності датчиків 14 (IД1) та 23 (ІД2). Дані через АЦП 27 надходять до ЕОМ 28 і профілометр-профілограф 29, де програмно обробляються і виводяться результати у вигляді таблиць та графіків. При досягненні рухомим блоком 2 другого кінця шліцевого валу 20 зупиняється електродвигун 8, індикаторні блоки 11, 22 відводять і ділильною головкою провертають шліцевий вал і продовжують вимірювання.

Пристосування повинно забезпечити необхідне положення заготовки відносно інструменту. Для партії заготовок це положення не $є$ постійним, а буває з полем розсіювання в деяких межах. Величину поля розсіювання положень міряльної бази заготовки для даного виконуваного розміру відносно інструменту називають похибкою $\varepsilon_{y}$. Для кожної операції, що виконується у конкретній технологічній системі, величину допустимої похибки встановлення можна визначити, використовуючи формулу технологічного допуску $\delta_{t}$

$$
\delta_{t}=\sqrt{\Delta_{y}^{2}+\Delta_{H}^{2}+\varepsilon_{\partial o n}^{2}+3 \Delta_{u}^{2}+3 \Delta_{T}^{2}}+\sum \Delta_{\Phi},
$$

де $\Delta_{y}$ - похибка виконуваного розміру, спричинена пружними відтисками елементів технологічної системи під впливом нестабільних сил різання;

$\Delta_{H}$ - похибка налагодження верстата;

$\Delta_{u}$ - похибка, викликана різним зношуванням різального інструменту;

$\varepsilon_{\text {до }}$ - допустима похибка установки в даному випадку $\varepsilon_{\text {доn }}=0$;

$\Delta_{T}$ - похибка, спричинена тепловими деформаціями технологічної системи;

$\sum \Delta_{\Phi} \quad$ - сумарна похибка форми оброблюваної поверхні, яка залежить від геометричних похибок верстата і деформації заготовки при її закріпленні [3].

Допуски форми і розміщення поверхонь для номінальних розмірів до 630 мм встановлюються згідно з вимогами ГОСТ 2.308-79. Допуски циліндричності, круглості профілю поздовжнього січення, площинності, прямолінійності призначають у тих випадках, коли вони менші від допуску відповідного розміру (виключенням є випадки, коли тлумачення граничних розмірів відрізняється від визначеного в СТ CEB 45-75). Рекомендують такі рівні відносної геометричної точності, які характеризуються співвідношенням між допуском форми або розміщення і допуском розміру: А - нормальна (=60\%); В - підвищена $(=40 \%) ; \mathrm{C}$ - висока $(=25 \%)$. В обгрунотованих випадках призначають допуск форми або розміщення менше $25 \%$ допуску розміру.

Із виразу (1) отримаємо

$$
\varepsilon_{\partial о n}=\sqrt{\left(\delta_{t}-\sum \Delta_{\Phi}\right)^{2}-\Delta_{y}^{2}-\Delta_{H}^{2}-3 \Delta_{u}^{2}-3 \Delta_{T}^{2}} .
$$

Запроектована схема встановлення заготовки повинна задовольняти вимогу: $\varepsilon_{y} \leq \varepsilon_{\partial o n}$.

Вимірювання непряме, тобто дане контрольне пристосування працює за відносним принципом і настроюється по еталону.

Висновки. На основі проведених досліджень можна зробити наступні висновки:

1. Встановлені технічні вимоги і норми точності шліцевих з'єднань і шліцевих валів сільськогосподарських машин під час їх виготовлення і відновлення.

2. Запропонована конструкція контрольного пристрою для заміру конструктивних параметрів щліцевих валів і їх шорсткості.

\section{Інформаційні джерела}

1. Воробьев Л.Н. Технология машиностроения и ремонт машин М.: Высшая школа, 1981,-344с.

2. Гевко Б.М. та інші. Технологія сільскогосподарського машинобудування К.:"Кондор", 2006, $-495 \mathrm{c}$.

3. Корсаков В.С. Основы конструирования приспособлений в машиностроении М.: Машиностроение, 1971,-387c. 
4. Патент на корисну модель №22755, Україна. Контрольний пристрій для заміру параметрів корпусних деталей ./ Гевко І.Б., та інші. - Бюл. №5, 2007.

Фльонц О.В., Кирик О.М.

Обособленное подразделение Национального университета биоресурсов и природопользования Украины «Бережанський агротехнический институт»

\title{
КОНТРОЛЬНОЕ УСТРОЙСТВО ДЛЯ ЗАМЕРА ПАРАМЕТРОВ ШЛИЦЕВОГО ВАЛОВ СЕЛЬСКОХОЗЯЙСТВЕННЫХ МАШИН
}

\begin{abstract}
Описаны виды шлицевых соединений и актуальность темы, приведены технические условия точности при изготовлении и восстановлении шлицевых валов сельскохозяйственных машин. Разработанная конструкиия контрольного устройства для замера конструктивных параметров и шероховатости при их изготовлении и восстановлении. Устройство для измерения параметров шлицевых валов выполнен в виде плиты, на которой размещень основные узльы и детали. Все показы поступают через аналогово-иифровой преобразователь к электронно вычислительной машины и профилографы-профилометры. Кроме этого для замера других конструктивных параметров илицевого вала и шероховатости других поверхностей могут устанавливаться дополнительные датчики аналогично вышеуказанным. Указанная последовательность работы устройства: в центры делительной головки и задней центр устанавливается эталонный шлицевой вал, с которого с помощью индуктивных датчиков снимаются все контролируемые параметры $и$ шероховатость поверхности $u$ устанавливают их допустимые предель. Приведены определения величины допустимой погрешности установки. Определены требование, которое должнна удовлетворять схема установки заготовки. Сделаны выводы о проведенных исследований.
\end{abstract}

Ключевые слова: соединение, вал, шероховатость, параметры, погрешность.

\section{Flonts O.V., Kyryk O.M.}

Separate subdivision of the National University of Life and Environmental Sciences of Ukraine "Berezhany Agrotechnical Institute"

\section{CONTROL DEVICE FOR MEASUREMENT OF PARAMETERS OF SLOT SHAFTS OF AGRICULTURAL MACHINES}

The types of splined joints and the relevance of the topic are described, the technical conditions of accuracy in the manufacture and restoration of splined shafts of agricultural machinery are given. The design of the control device for measurement of design parameters and roughness at their manufacturing and restoration is developed. The device for measuring the parameters of the splined shafts is made in the form of a plate on which the main components and parts are placed. All readings come through an analog-to-digital converter to an electronic computer and a profilographprofilometer. In addition, to measure other design parameters of the splined shaft and the roughness of other surfaces can be installed additional sensors similar to the above. The sequence of operation of the device is specified: in the centers of a dividing head and the back center the reference splined shaft from which by means of inductive sensors all controlled parameters and surface roughness are removed and their admissible limits are established is established. The definition of the value of the allowable installation error is given. The requirement which the scheme of installation of preparation has to satisfy is defined. Conclusions are made on the conducted researches.

Keywords: connection, shaft, roughness, parameters, error. 